\title{
МЛЭ рост сложных фотоприёмных, лазерных и nBn структур на основе твердых растворов CdHgTe
}

\author{
Н.Н. Михайлов ${ }^{1}$, С.А. Дворецкий ${ }^{1,3}$, Р.В. Меньшиков ${ }^{1}$, В.Г. Ремесник ${ }^{1}$, И.Н.Ужаков ${ }^{1}$, В.А. Швец ${ }^{1,2}$ \\ ${ }^{1}$ Институт физики полупроводников им. А.В. Ржанова СО РАН, \\ Новосибирск, 630090, Лаврентьева 13 \\ ${ }^{2}$ Новосибирский государственный университет, Новосибирск, 630090, ул. Пирогова 2. \\ ${ }^{2}$ Томский государственный университет, Томск, Россия, 634050, пр. Ленина 36. \\ тел: +7 (383) 330-4967, факс:+7 (383)330-4967, эл.nочта: mikhailov@isp.nsc.ru
}

DOI 10.34077/RCSP2021-45

Рассмотрены особенности выращивания сложных гетероструктур на основе твердого раствора $\mathrm{CdHgTe}$ и $\mathrm{HgCdTe} / \mathrm{HgTe}$ квантовых ям (КЯ) на альтернативных подложках из (013) $\mathrm{CdTe} / \mathrm{ZnTe} / \mathrm{GaAs}$ диаметром до 3-х дюймов методом молекулярно-лучевой эпитаксии с in situ эллипсометрическим контролем состава и толщины на сверхвысоковакуумной установке "Обь-М" с модернизированной системой молекулярных источников. Для лазерных структур при последовательно росте выращиваются толстые волноводные слои $\mathrm{CdHgTe}$ с составами 0,7-0,95 молярных долей СdTе и толщиной 0.3-10 мкм, в объеме которых встроены квантовые ямы (КЯ) $\mathrm{HgCdTe} / \mathrm{HgTe} / \mathrm{HgCdTe}$ в количестве от 3 до 15 КЯ с такими параметрами: состав в КЯ и барьерах 30 нм составлял менее 0,05 и $0,7-0,95$ и толщиной $2.5-7,8$ нм и 30 нм соответственно. Такие структуры обеспечивают длину волны стимулированного излучения в диапазоне от 3 до 31 мкм.
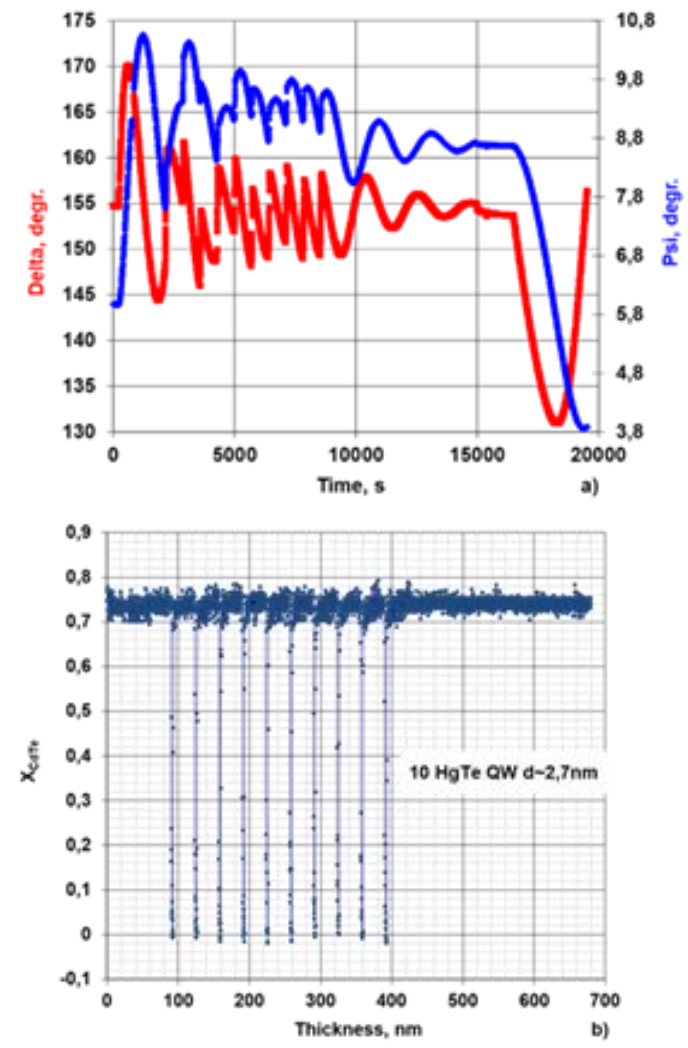

Для инфракрасных (ИК) фотоприемников (ФП) на основе множественных КЯ (до 200), нового материала как альтернативы $\mathrm{HgCdTe}$, проведены исследование процессов их выращивания. Толщина барьерных слоев и КЯ варьировались и составили 30-40 нм и 2,5-8 нм, соответственно. Из измерений спектров поглощения и фотопроводимости экспериментально установлено, что энергетическое положение уровней размерного квантования изменяется обратно пропорционально с увеличением толщины КЯ при этом длинноволновая граница смещается в область бо́льших длин волн. Разработанные особенности технологических процессов роста с прецизионными эллипсометрическим контролем состава и толщины на нанометровом уровне in-situ и использованием метода “эффективной” подложки позволяет воспроизводимо выращивать сложные излучающие лазерных и фотоприёмные гетеростуктуры в широком инфракрасном диапазоне длин волн. Также в качестве альтернативы для ИК ФП рассматривают униполярные $\mathrm{nBn}$ структуры с поглощающими толстыми узкозонными слоями с составами $\sim(02-0,3)$ и встроенными в их объеме широкозонными барьерными слоями с составами $\sim 0.7$ и толщиной $(0.2-0.5)$ нм. На рисунке представлены данные по выращиванию лазерной структуры с 10-ю НgТе КЯ толщиной 2,7 нм: а - измерения

эллипсометрических параметров в процессе роста; b) - рассчитанный профиль распределения состава вблизи КЯ. Данный тип структур обеспечивает длину волны стимулированного излучения $~ 3$ мкм при температурах $\leq 10^{\circ} \mathrm{C}$.

Для $\mathrm{nBn}$ структур, содержащих последовательно рабочий n-слой с составами $\sim 0,3$, толщиной в несколько мкм, легированных индием до $(8-50) \times 10^{15} \mathrm{~cm}^{-3}$, широкозонный барьерный слой с составом $\mathrm{X}_{\mathrm{CdTe}} \sim 0,7$ толщиной несколько десятых мкм и контактный слой с составом, превышающим состав рабочего слоя, толщиной $\sim 1$ мкм и уровнем легирования индием $(5-30) \times 10^{16} \mathrm{~cm}^{-3}$. ИК ФП фотоприемники на основе таких $\mathrm{nBn}$ структур имели пониженные темновые токи и имели высокую чувствительность в диапазоне 3-5 мкм, незначительно уступающую лучшим зарубежным данным и практически лежат к кривой "RULE 07”, определяющего лучшие данные для ИК ФП.

Работа выполнена при частичной финансовой поддержке РФФИ (проект №18-29-20053). 